\title{
Congressmen in last-ditch THORP appeal
}

Washington. A number of leading members of the US Congress have written to John Major, the British prime minister, asking for any decision on starting up the thermal oxide reprocessing plant (THORP) in Cumbria to be delayed until a new public inquiry is held into the need for the multibillion pound plant.

The letter has also been sent to US President Bill Clinton and the Japanese Prime Minister Morihiro Hosokawa, arguing that the operation of the plant would "contravene the stated policies of Japan and the United States" by adding to the world's plutonium stockpiles.

Signed by senators Jeff Bingaman (Democrat, New Mexico), Dale Bumpers (Democrat, Arkansas) and Tom Harkin (Democrat, Iowa), as well as 30 members of the House of Representatives, the letter calls on the Clinton administration to help Britain and Japan renegotiate existing THORP agreements.

A decision on whether to start up the nuclear reprocessing plant is expected soon, although continuing delays are fuelling speculation that the British Treasury whose concerns about uncontrollable costs are reported to have been the main reason for delay so far - is fighting a late rearguard action against approval.

A group of congressmen led by Pete Stark (Democrat, California) and Joseph Kennedy (Democrat, Massachusetts) have also written to Hazel O'Leary, the Secretary of Energy, asking her to turn down a request from Switzerland to send fuel to THORP for reprocessing.

The United States has full control over the Swiss material under supply agreements between the two countries, as it has over Japanese fuel. Japan, however, has negotiated a waiver removing the requirement that everything it does with its fuel requires that explicit approval is given by the US Department of Energy.

Despite pressure from environmentalists and others, Clinton has declined to take a public position on THORP, arguing that US intervention might offend both Britain and the plant's largest customer, Japan.

But opponents of the plant are suggesting that one factor behind Clinton's reluctance to criticize THORP is a feeling among some US officials that Japan will eventually need its own nuclear weapons capability, and that this would also be in the best interests of the United States. Plutonium from THORP would be needed to achieve this goal.

Paul Leventhal, for example, president of the Washington-based Nuclear Control Institute, says that the plutonium surplus that will be acquired by Japan if THORP comes on stream "makes no sense, except to open up a weapons option". He claims that the development of nuclear weapons by Japan "is not necessarily regarded as a danger".

But Japanese officials vigorously deny this claim, and others support their argu-

\section{IMAGE \\ UNAVAILABLE FOR COPYRIGHT REASONS}

ments that the allegation is far-fetched, given overwhelming public antipathy towards nuclear weapons in Japan. "I would never accuse the Japanese of having any intention of making nuclear weapons," says Andrew Duncan of the International Institute for

Strategic Studies in London.

Meanwhile the Danish Environment Minister, Svend Auken, has urged Britain not to go ahead with the operation of THORP because of the 900 per cent increase in radioactivity that would be emitted into the sea as a result.

A spokesman for Britain's Department of the Environment rejected charges that the increased emissions would pose a serious risk to the environment, arguing that THORP's emissions would represent "a 900 per cent increase from practically nothing".

But speaking at a meeting in Copenhagen last week attended by representatives of the eight European countries bordering on the North Sea, Auken said that there was a "strong wish in the North Sea countries that the decision will be a no".

Colin Macilwain

\section{UCSF goes solo with venture fund}

San Francisco. The University of California, San Francisco (UCSF), is planning to establish its own venture capital fund to help develop faculty inventions into commercial products, following the apparent collapse of plans for a state-wide university system.

The central administration of the University of California had proposed setting up a commercial company to develop inventions from all of its nine campuses. But many faculty members objected to the proposal, claiming that it would reduce the authority of individual campuses, dampen support for university research and drain patent income away from education.

A report on the proposal, due to be published next February, is now expected to advise against the system-wide plan. But it will suggest that individual campuses expand their technology transfer offices independently, providing both a source of income and a means of transferring the results of research to society.

Joseph Martin, the chancellor of UCSF, is already planning to expand the role of its licensing office. For example, this would take on responsibility for compiling a list of promising inventions on the campus, and for building relationships with both faculty members and potential commercial collaborators.

Martin says he also is considering a UCSF-managed venture capital fund to nurture inventions not quite ready to attract commercial support. The technology would be developed at the university, probably inside special 'incubator' laboratories. Capital is likely to cpme from both US and
Pacific Rim companies, as well as government agencies and venture capitalists, he says.

Martin acknowledges the need to deal with faculty concerns. In particular, he says, the new arrangements must not take faculty members away from teaching and research, or result in their work being driven purely by commercial considerations. Also, he says federal funded research should be separated from commercially-orientated work.

But not all faculty members are happy, some fear that venture capital funding will harm its central mission of unfettered research and teaching. Keith Yamamoto, vicechairman of the faculty of biochemistry and biophysics, says he supports UCSF's efforts to expand its patenting abilities and build alliances that would bring commercial resources back to campus.

But Yamamoto says UCSF should stop short of starting companies. "Technology transfer is critical and valuable," he says. "But it is dangerous for universities to become involved in funding or encouraging faculty to set up companies based on their inventions."

Martin says UCSF will study the implications of stock ownership, and intends to form a faculty advisory committee. But he argues that, under certain guidelines, the institution should be able to share the ownership of ventures with both faculty members and outside investors.

Martin has asked an advisory committee of prominent industrialists to investigate technology transfer mechanisms, looking at the experience of other universities.

Sally Lehrman 